Dept. of Animal Husbandry,

Faculty of Vet. Med., Alexandria Univ.,

Head of Dept. Prof. Dr. T.H. Moustafa.

\title{
SOME FACTORS AFFECTING SOUNDNESS AND BEHAVIOUR OF DAIRY ANIMALS
}

(With 4 Tables)

\author{
By \\ H. SAMAHA; I.S. MENEEH and A. ALI \\ (Received at 16/3/1989)
}

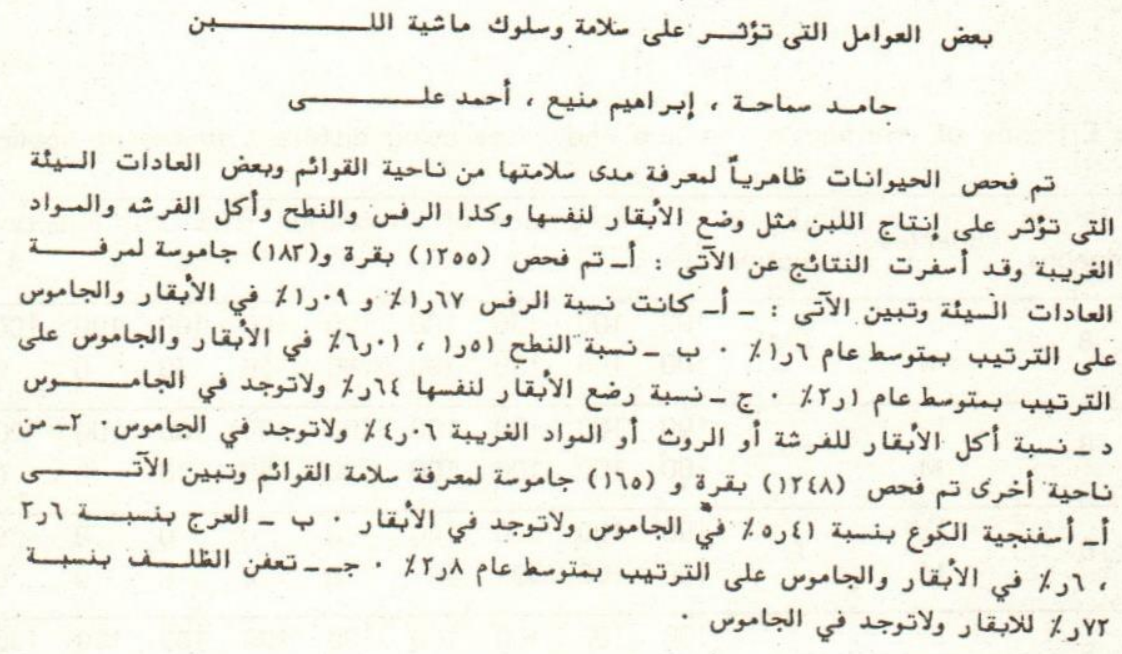

\section{SUMMARY}

This work was carried out on 1255 dairy cows and 183 buffaloes in two types of housing, cow and milk house systems to investigate the effect of housing system on the soundness and behaviour of such animals. Moreover, 1248 dairy cows and 165 buffaloes were examined for detection of capped elbow, laminitis, foot rot and overgrowth of claws.

The overall percentages of incidence of kicking, stricking, suckling and eating of bedding were found to be 1.6, 2.1, 0.56 and $3.5 \%$ respectively in investigated animals due to overcrowding of the animals.

The incidence percentages of limb affections were found to be 0.5 , 2.8 and 1.8 for capped elbow, foot rot and claw overgrowth respectively.

\section{INTRODUCTION}

Soundness of dairy cattle and buffaloes is very important for their health and production. Livestock may fail to exhabit its true production capabilities due to impro-

Assiut Vet.Med.J. Vol. 22, No. 44, January, 1990. 


\section{H. SAMAHA, et al.}

per housing design and management. The effect of housing system on the occurrence of vices and limb affections was studied by several workers (FRANK, 1959; MERCK, 1973; O.CONNER, 1984; MILLER, 1979; BANERJEE, 1982 and GLYN, 1983). The aim of the present study was planned to point out the most common factors affecting soundness of dairy cattle and buffaloes.

\section{MATERIAL and METHODS}

Two systems of enclosing dairy cattle and buffaloes were met with in the present investigation:

1 - Cow house system (2 housing) provided with rice straw bedding material and concrete floor.

2 - Milk house system (4 housing) with daity floor and not provided with any bedding material.

1255 dairy cows and 183 buffaloes were observed twice daily at the morning and afternoon for the following vices:
a) Suckling
c) Kicking
b) Stricking
d) Eating of bedding

The above mentioned vices were reobserved again at an interval of 15 days for a period of 6 months.

On the other hand, 1248 dairy cows and 165 buffaloes were examined clinically for detection of capped elbow, laminitis, foot rot, and overgrowth of the claws. Capped elbow and overgrowth of the claws were detected by examination of the affected parts while laminitis and foot rot were detected by observation of the uneasiness in the animal movement and mainpulation of the affected parts.

\section{RESULTS}

Are presented in tables $(1-4)$.

\section{DISCUSSION}

The data presented in table (1) revealed that the percentage of kicking among investigated dairy cattle and buffaloes was found to be 1.67 and 1.09 respectively. In addition the incidence of kicking among dairy cattle in cow house systems, and milk house systems was found to be 1.03 and 2.15 respectively (Table 2). On the other hand; it has been observed that kicking of buffaloes was only present in animals enclosed in cow house systems (1.8\%) (Table 2). Which may be attributed to rough handling by unskilled milkers, udder or teat affections and the presence of pieces of stones (BANERJEE, 1982 and GLYN, 1983).

The results illustrated in table (1) revealed that cattle suckled itself at an incidence of $0.64 \%$. Moreover, it has been found that this vice was noticed at a high incidence in milk house systems (0.66\%) than in cow house systems (0.62\%). Table (2) which 
may be attributed to cases of mastitis predominating in milk hose systems with the traditional presence of dirty soil (SAINSBURRY and SAINSBURRY, 1979). Moreover, inflammation or cracked teat and udder resulted fiom uneven surface of the floor and insufficient bedding can lead to suclking of the cow to itself (MOELLER, et al. 1974 and BANERJEE, 1982).

It can be observed from the results given in table (1) that the percentage of stricking was found to be 1.51 and 6.01 in dairy cattle and buffaloes respectively. In addition, the percentage was found to be 2.52 and 13.9 in dairy cattle and buffaloes sheltered in milk house systems (table 2). In the availaple literatures, no references mentioned any incidence of stricking except HAFEZ (1975) and MAHANTA (1976) who stated that housing of dairy animals in yards can predispose to stricking.

In view of data presented in table (1) the incidence of pica in dairy cattle was found to be $4.06 \%$. It has been found that this vice was much common among dairy cattle enclosed in milk house systems (6.1\%) than those in cow house system (1.03\%). During the course of the present work, pica was not observed among buffaloes. Bad management, unclean bedding and mineral deficiency in rations were reported to be the predisposing factors of such vice which is responsible for indigestion in most cases (MC-DONALD, et al. 1973; BLOOD and HENDERSON, 1974 and MILLER, 1979).

Capped elbow was only met with in buffaloes at an incidence of $5.45 \%$ (table 3). A higher incidence of capped elbow (7.14\%) was encountered in animal enclosed in cow house systems than milk house system (1.89\%) (table 4). The presence of hard floor (O'CONNER, 1950) insufficient bedding material and repeated trauma (FRANK, 1959) kicking and recumbancy of buffaloe and cattle for a long period of time, (MERCK, 1973) and cirect injury due to wires, nails were reported as predisposing factors for capped elbow.

Table (3) show that the incidence percentages of laminitis were found to be 3.6 and 0.6 in dairy cattle and buffales respectively. In addition 4.52 and $0.89 \%$ of investigated dairy cattle and buffaloes respectively enclosed in cow house systems were found to be affected with laminitis, while $3.08 \%$ of dairy cattle kept in milk house systems were recorded to be suffered from such an affection (table 4).

Trauma of the foot caused by contact with hard surfaces of the building, rough concrete floor, poor building designs, insufficient bedding, exposure to damp surfaces and injuries caused by pieces of stone or gravel getting in between the claws were reported by several investigators to be the main causes of laminitis (WEAVER, 1971; DEREK, 1982) EWER, 1982; GLYN, 1983 and DEREK, 1984).

Foot rot was met with at an incidence of $0.72 \%$ in dairy cattle (table 4). Milk house systems has a higher percentage of foot rot among dairy cattle (1.7\%) than cow house system $(0.2 \%$ ) (table 4) which may be due to the presence of dirty floor in the milk house system with, which urine and solid manure become mixed or absorbed by them leading to a constantly damp and cold floor (SCHMOLDT and HYDEN, 1973), 


\section{H. SAMAHA, et al.}

this practice which is oftenly resorted in order to ensure a good fertilizer, was reported as a predisposing factor in cases of foot rot in dairy cattle and buffaloes (ADAMS, 1960; FRANK, 1964; RAVEN, 1971; BLOOD and HENDERSON, 1974; ABDEL BARY, 1980 and SAMAHA, 1983). The frequency of overgrowth of claw is illustrated in table (3) the incidence of claw overgrowth was found to be 1.84 and $4.85 \%$ in dairy cattle and buffaloes respectively. However, claw overgrowth was higher among dairy cattle in cow house system (3.9\%) than those kept in milk house system (0.53\%) (Table 4) which may be due to prolonged housing of animal inside the house (PRENTICE, 1973; KING' 1978 and DAVID, 1981). From the observed results we can conclude that kicking, stricking, suckling and eating bedding was found to be high in milk house system than in cow house system due to over-crowding and bulling of the animals. In addition capped elbow and claw overgrowth was high in animals housed in cow house system due to the repeated trauma and recumbancy of the animal for a long period of time, direct injury from nail, wires and other sharp objects as well as a prolonged housing of animals inside the house were predisposing factor for capped elbow and claw over-growth, while laminitis and footrot was prevalent in milk house system due to the presence of cold and damp earth floor.

\section{REFERENCES}

Abdel-Bary, M. (1980): Factors affecting the soundness of hoofs in equine and claws in cattle. M.V.Sc. Thesis, Vet. Med., Alex. Univ.

Adams, O.R. (1960): Foot rot in cattle. J.A.V.M.A. 136, 589599.

Banerjee, G.C. (1982): A text book of animal husbandry. 5th Ed. Oxford Publishing Co.

Blood, D.C. and Henderson, J.A. (1974): Veterinary Medicine. 4th Ed. Bailliere Tindal London.

David, W.A. (1981): Lameness in cattle. 2nd Ed. Wright Scientechica.

Derek, B. (1982): Hoof lameness in dairy cattle. University of reading, reading RG6

Derek, B. (1984): Lameness in dairy cattle. University of reading, RG6 2AT-London. Ewer, T.K. (1982): Practical animal husbandry. 1st Ed. Prestol-England.

Frank, G.A. (1959): Veterinary Surgery. 5th Ed. Burgess Publishing Co. Minneopolis. Frank, E.R. (1964): Veterinary Surgery. 6th Ed. Burgess Publishing Co. Minneopolis. Glyn, J. (1983): Tv. Vet. Book for stock farmers. I. 4th Ed. Norwich Ltd. London.

Hafez, E.S. (1975): The behaviour of domestic animals. 3rd Ed. Bailliere-Tindal-London. King, J.O. (1978): An introduction to animal husbandry. 1st Ed. Oxford-London. Mahanta, K.C. (1976): A text book of animal husbandry. 1st Ed. Asia Publishing house,
New York.

McDonald, P.; Edwards, R.A. and Greenhalgh, J.F. (1973): Animal nutrition 2nd Ed. Longman group Limited-Londor.

Merck, J. (1973): The merck Vet. Manual. 4th Ed. ING Co. U.S.A.

Miller, W.J. (1979): Dairy cattle feeding and nutrition. Academic Press-London. 


\section{SOUNDNESS, BEHAVIOUR, DAIRY ANIMALS}

Moeller, N.J.; Hill, D.L. and Albight, J.L. (1974): Concrete free stalls cause udder health, leg problems. Hoard's Dairyman 119 (12): 767-776.

O'Conner, J.J. (1950): Dollar's Veterinary Surgery. 4th Ed. Balliere Tindall and Cox-London. O'Conner, J.J. (1984): Dollar's Veterinary Surgery. 5th Ed. Bailliere Tindall and Cox-
London.

Prentice, D.E. (1973): Growth and wear rates of hoof horn in Ayrshire cattle. Vet. Sci., 14 (3): 285-290.

Raven, E.J. (1971): The specific contagious inflammation of the interdigital skin in cattle. Vet. Med. Review. 2/3: 223-247.

Sainsbury, D. and Sainsbury, R. (1979): Livestock health and housing. 2nd Ed. Bailliere Tindal-London.

Schmoldt, P. and Hyden, H. (1973): Causes of locomoter disorders in young cattle on slatted floor. Monatsheft Fur Veterinarmedizin, 28 (20): 767-773.

Weaver, B.; Mitchell, D. and Hallows, B. (1986): Calf rearing. 1st Ed. Redwood Burn Limited-London.

Table (1)

The incidence of vices in dairy cattle and buffaloes

\begin{tabular}{lccccccccc}
\hline & \multicolumn{1}{c}{ Vices } \\
\cline { 2 - 10 } Animal species & $\begin{array}{c}\text { Total } \\
\text { No. }\end{array}$ & Kicking & Stricking & Suckling & $\begin{array}{c}\text { Fating of } \\
\text { bedding }\end{array}$ \\
\cline { 2 - 11 } & & No. & $\%$ & No. & $\%$ & No. & $\%$ & No. & $\%$ \\
\hline $\begin{array}{l}\text { Dairy cattle } \\
\text { Buffaloes }\end{array}$ & 1255 & 21 & 1.67 & 19 & 1.51 & 8 & 0.64 & 51 & 4.06 \\
\cline { 3 - 11 } Total & 183 & 2 & 1.09 & 11 & 6.01 & - & - & - & - \\
\hline
\end{tabular}

Assiut Vet.Med.J. Vol. 22, No. 44, January, 1990. 
H. SAMAHA, et al.

Table (2)

The percentage of vices and types of housing

\begin{tabular}{|c|c|c|c|c|c|c|c|c|c|c|c|c|}
\hline \multirow{2}{*}{$\begin{array}{l}\text { Type of housing } \\
\text { and vices }\end{array}$} & \multicolumn{12}{|c|}{ Cows house system } \\
\hline & \multicolumn{3}{|c|}{ Kicking } & \multicolumn{3}{|c|}{ Stricking } & \multicolumn{3}{|c|}{ Suckling } & \multicolumn{2}{|c|}{ Pica } & \\
\hline Animal species & No. & + ve & $\%$ & No. & +ve & $\%$ & No. & + ve & $\%$ & No. & $+\mathrm{ve}$ & $\%$ \\
\hline Dairy cattle & 487 & 51 & 1.03 & 487 & - & - & 487 & 3 & 0.62 & 487 & 5 & 1.03 \\
\hline Buffaloes & 111 & 2 & 1.08 & 111 & 1 & 0.90 & 111 & - & - & 111 & - & - \\
\hline
\end{tabular}

Type of housing

Cows house system

and vices

\begin{tabular}{|c|c|c|c|c|c|c|c|c|c|c|c|c|}
\hline \multirow{2}{*}{ Animal species } & \multicolumn{3}{|c|}{ Kicking } & \multicolumn{4}{|c|}{ Stricking } & \multicolumn{2}{|c|}{ Suckling } & \multicolumn{3}{|c|}{ Pica } \\
\hline & No. & + ve & $\%$ & No. & + ve & $\%$ & No. & + ve & $\%$ & No. & +ve & $\%$ \\
\hline Dairy cattle & 754 & 16 & 2.15 & 754 & 19 & 2.52 & 754 & 5 & 0.66 & 754 & 46 & 6.1 \\
\hline Buffaloes & 111 & - & - & 111 & 10 & 13.9 & 111 & - & - & 111 & - & - \\
\hline
\end{tabular}

Table (3)

The incidence of limb affections from elbow joint until the claws

\begin{tabular}{lrrrrrrrrrr}
\hline \multirow{2}{*}{$\begin{array}{l}\text { Animal species } \\
\text { Skin affection }\end{array}$} & \multicolumn{3}{c}{ Dairy cattle } & \multicolumn{3}{c}{ Buffaloes } & \multicolumn{2}{c}{ Total } \\
\cline { 2 - 10 } & No. & + ve & $\%$ & No. & + ve & $\%$ & No. & +ve & $\%$ \\
\hline Capped elbow & 1248 & - & - & 165 & 9 & 5.45 & 1763 & 9 & 0.50 \\
Laminitis & 1248 & 45 & 3.60 & 165 & 0.60 & 0.60 & 1763 & 50 & 2.80 \\
Foot rot & 1248 & 9 & 0.72 & 165 & - & - & 1763 & 17 & 0.96 \\
Claw overgrowth & 1248 & 23 & 1.84 & 165 & 6.00 & 4.85 & 1763 & 31 & 1.80 \\
\hline
\end{tabular}


SOUNDNESS, BEHAVIOUR, DAIRY ANIMALS

Table (4)

The incidence of limb affections in different types of housing

\begin{tabular}{|c|c|c|c|c|c|c|c|c|c|c|c|c|}
\hline \multirow{3}{*}{$\begin{array}{l}\text { Type of housing } \\
\text { and limb } \\
\text { affection } \\
\text { Animal-species }\end{array}$} & \multicolumn{12}{|c|}{ Cows house system } \\
\hline & \multicolumn{3}{|c|}{ Capped elbow' } & \multicolumn{3}{|c|}{ Laminitis } & \multicolumn{3}{|c|}{ Foot rot } & \multicolumn{3}{|c|}{ Claw overgrowth } \\
\hline & No.' & +ve & $\%$ & No. & + ve & $\%$ & No. & + ve & $\%$ & No. & +ve & $\%$ \\
\hline Dairy cattle & 487 & - & - & 487 & 22 & 4.52 & 487 & 1 & 0.2 & 487 & 19 & 3.90 \\
\hline Buffaloes & 112 & 8 & 7.14 & 112 & 1 & 0.89 & 112 & - & - & 112 & 7 & 6.25 \\
\hline \multirow{2}{*}{$\begin{array}{l}\text { Type of housing } \\
\text { and limb } \\
\text { affection }\end{array}$} & \multicolumn{12}{|c|}{ Milk house system } \\
\hline & \multicolumn{3}{|c|}{ Capped elbow } & \multicolumn{2}{|c|}{ Laminitis } & & \multicolumn{3}{|c|}{ Foot rot } & \multicolumn{3}{|c|}{ Claw overgrowth } \\
\hline Animal species & No. & $+\mathrm{ve}$ & $\%$ & No. & $+v e$ & $\%$ & No. & + ve & $\%$ & No. & +ve & $\%$ \\
\hline Dairy cattle & 447 & - & - & 747 & 23 & 3.08 & 747 & 8 & 1.07 & 747 & 4 & 0.53 \\
\hline Buffaloes & 53 & 1 & 1.89 & 53 & - & - & 53 & - & - & 53 & 1 & 1.89 \\
\hline
\end{tabular}

Assiut Vet.Med.J. Vol. 22, No. 44, January, 1990. 